\title{
ORYGENES W PISMACH I WYSTĄPIENIACH JANA PAWHA II
}

Podchodząc do takiego tematu dobrze byłoby wiedzieć, jakie teksty rzeczywiście wyszły spod pióra Jana Pawła, a jakie są dziełem jego sekretarzy. Ta wiedza jest nam jednak niedostępna. Spróbujmy jednak ułożyć te wypowiedzi mniej więcej chronologicznie, zakładając hipotetycznie, że u początków swej posługi papieskiej Jan Paweł II więcej pisał sam, niż w ostatnich latach.

Być może pierwszą wzmiankę o Orygenesie znajdujemy w przemówieniu do pielgrzymów z Piacenzy w 1979 roku; Ojciec Święty odniósł się wtedy do sceny pod krzyżem Jezusa opisanej w Ewangelii według św. Jana mówiąc:

„Starożytni Ojcowie Kościoła widzieli w tym epizodzie, bardzo prostym na pierwszy rzut oka, głęboki sens teologiczny. Już Orygenes utożsamiał Jana apostoła z każdym chrześcijaninem, a później znajdujemy coraz częstsze odwołania do tego tekstu dla wykazywania powszechnego macierzyństwa Maryi"

Tak więc w pierwszym przywołaniu Orygenesa przez Jana Pawła II widzimy go jako Ojca Kościoła. Pamiętajmy, że z racji jego potępienia przez wieki, był on cytowany co najwyżej jako „pisarz kościelny”, ale nie Ojciec Kościoła. Również do Ojców zaliczył Papież Orygenesa w katechezie podczas audiencji ogólnej w lipcu 2003 roku. Komentował wtedy biblijny opis stworzenia i powiedział:

„Oddajmy głos Ojcom Kościoła takim jak Orygenes, Hipolit, Bazyli z Cezarei, Ambroży z Mediolanu, którzy komentowali opowieść o sześciu dniach stworzenia”².

W tym samym roku, w którym spotkał się z wiernymi z Piacenzy, wspomina jeszcze Papież Orygenesa w Adhortacji Apostolskiej Catechesi Tradendae. Czytamy tam:

„Kościół prowadzi nadal nauczycielską posługę Apostołów i ich pierwszych współpracowników. Stając się bowiem sam, dzień po dniu, uczniem Pana, nazy-

${ }^{1}$ La communità cristiana si costruisce sul fondamento degli Apostoli 2, w: Insegnamenti di Giovanni Paolo II, II/2, s. 12.

${ }^{2}$ Cantico di Daniele 3, 57 - 88, 56: Ogni creatura lodi il Signore 5, w: Insegnamenti XXV/2, s. 47. 
wany jest słusznie «Matką i Mistrzynią». Już bowiem okres poapostolski, od Klemensa Rzymskiego do Orygenesa, wydał wybitne dzieła. Potem obserwujemy to znaczące zjawisko, a mianowicie, że biskupi i pasterze, spośród najwybitniejszych, zwłaszcza w III i IV wieku, uznają za szczególnie ważny dział swego biskupiego posługiwania obowiązek ustnego nauczania lub pisania traktatów katechetycznych. W okresie Cyryla Jerozolimskiego, Jana Chryzostoma, Ambrożego i Augustyna spod pióra wielu Ojców Kościoła wyszły dzieła, stanowiące dla nas najwybitniejsze wzory"3.

Samo postawienie Orygenesa w tak zacnym gronie Ojców świadczyć może o uszanowaniu jego twórczości przez Papieża, aczkolwiek jest to tylko wzmianka.

Więcej niż wzmiankę znajdujemy w encyklice Fides et ratio; pisząc o wzajemnych wpływach wiary i filozofii, Jan Paweł II uczy:

„W dziejach tego procesu można jednakże dostrzec przejawy krytycznego przyswajania sobie myśli filozoficznej przez myślicieli chrześcijańskich. Pośród pierwszych przykładów, jakie można napotkać, znamienna jest z pewnością postać Orygenesa. Odpierając zarzuty wysuwane przez filozofa Celsusa, Orygenes posługuje się filozofią platońską, aby oprzeć na niej swoje argumenty i odpowiedzi. Nawiązując do licznych elementów myśli platońskiej, zaczyna kształtować pierwszą formę teologii chrześcijańskiej. Aż do tamtego czasu bowiem sama nazwa oraz idea teologii jako racjonalnej refleksji o Bogu była jeszcze związana z kulturą grecką, z której się wywodziła. W filozofii arystotelesowskiej na przykład, termin «teologia» oznaczał najbardziej wzniosłą część i prawdziwe szczytowe osiągnięcie refleksji filozoficznej. Natomiast w świetle chrześcijańskiego Objawienia to, co uprzednio oznaczało ogólną doktrynę o bóstwach, zyskiwało zupełnie nowy sens, określając refleksję podjętą przez wierzącego w celu sformułowania prawdziwej doktryny o Bogu. Ta rozwijająca się stopniowo nowa myśl chrześcijańska posługiwała się filozofią, zarazem jednak starała się wyraźnie od niej odróżniać. Historia pokazuje, że nawet myśl platońska przejęta przez teologię przeszła głębokie przekształcenia, zwłaszcza takie jej elementy jak nieśmiertelność duszy, przebóstwienie człowieka i pochodzenie zła"4.

Orygenesowi zostaje tutaj przypisana funkcja prekursora teologii jako nauki. Zauważył to również późniejszy następca Jana Pawła II, kard. Józef Ratzinger, który podczas prezentacji encykliki w „Osservatore Romano” tak się wypowiedział:

„Przede wszystkim wraz z Orygenesem widać narodziny teologii, która wymienia i rozwija proste twierdzenia Symbolu, teologii, która rozwija spójną doktrynę i nie ogranicza się do narracji i wyjaśniania poszczególnych etapów Bożej ekonomii. Metoda i nauka Orygenesa naznaczą cała historię teologii; nawet jeśli dzisiaj próbuje się stonować powszechny dawniej osąd dotyczący organicznej zwartości

${ }^{3}$ Catechesi tradendae (16 X 1979) 12, w: Adhortacje Apostolskie Ojca Świętego Jana Pawła II, t. 1, Kraków 2006, 21.

${ }^{4}$ Fides et ratio (14 IX 1998) 39, w: Encykliki Ojca Świętego Jana Pawła II, Kraków 2006, 1125. 
doktrynalnej konstrukcji orygenesowskiej, nie zmienia to w niczym faktu, że Orygenes, podejmując wyzwania gnozy, otworzył nową drogę dla teologii. Słusznie więc Papież pisze, że między pierwszymi przykładami «krytycznego przyswajania myśli filozoficznej przez myślicieli chrześcijańskich [...] znamienna jest z pewnością postać Orygenesa». Aleksandryjczyk proponuje bowiem pewną duchową drogę, na której wiara i rozum, poznanie, kontemplacja i doświadczenie mistyczne Boga, nie zlewając się bynajmniej, przenikają się wzajemnie i ciągle pozostają do dyspozycji każdego chrześcijanina, by podążał drogą doskonałości" 5 .

Kardynał czyni tu zapewne aluzję do dyskusji na temat tego, do jakiego stopnia Orygenes jest systematycznym teologiem. Znane jest stanowisko o. H. Crouzela, który dowodził w wielu swoich pismach, że nie ma u Orygenesa teologii systematycznej, nawet w jego Zasadach, ale teologia gymnastike, jak lubił mówić, ciągle poszukująca i wyżej wręcz ceniąca samo poszukiwanie, niż efekty tego poszukiwania, które Orygenes uważał za ciągle niewystarczające i hipotetyczne. Znowu więc widzimy naszego Aleksandryjczyka w roli prekursora teologii, a głos ówczesnego prefekta Kongregacji d/s Doktryny Wiary jest tu o tyle ważny, że należał on do najściślejszego grona współpracowników Papieża w przygotowywaniu jego ważniejszych wystąpień. Nie dziwi też, że na łamach tegoż „Osservatore Romano” Enrico dal Covolo, w artykule o encyklice Fides et ratio również zwrócił uwagę na powołanie się w niej na Orygenesa i należycie je wyakcentował, gdyż jego zasługi i znaczenie podkreśla on ilekroć tylko ma okazję $^{6}$.

W osobistej książce, jaką jest bez wątpienia Przekroczyć próg nadziei, Papież również odwołał się do autorytetu Orygenesa, i to w nauczaniu o sprawach ostatecznych; wymienia go w zacnym towarzystwie M. Bułhakowa i H. Ursa von Balthasara ${ }^{7}$. Spotkała go za to szydercza krytyka ze strony członków Bractwa św. Piusa X. W artykule programowym czasopisma „Sodalitium”, przeczytałem na marginesie rzeczonego artykułu: „Kim są Wielcy dla Wojtyły: Orygenes (potępiony przez Kościół właśnie z powodu piekła), Bułhakow (heretyk gnostycki) i Balthasar (o którym można by powiedzieć wiele)!!! Święty Augustyn? Święty Tomasz? Ale gdzież tam! Kim oni są?".

Papież jednak się tym pewnie nie przejął, gdyż i gdzie indziej bardzo wyraźnie nawiązuje do Orygenesowej hipotezy apokatastazy. Widzimy to w liście En cette année, z 2 czerwca 1998 do Raymonda Séguy, biskupa Autun, Châlon i Mâcon, opata z Cluny:

5 Por. J. Ratzinger, Il magisterio dei Padri nell'Enciclica „Fides et ratio” 5, OsRom 138 (1998) nr $262(13$ XI) s. 4.

${ }^{6}$ Por. E. Dal Covolo, L'itinerario dei primi secoli cristiani, OsRom 138 (1998) nr 263 (14 XI) s. 8.

${ }^{7}$ Por. Przekroczyć próg nadziei 28, Lublin 1995, s. 147: „Problem piekła zawsze niepokoił wszelkie umysły w Kościele od samego początku, od Orygenesa do naszych czasów, do Michała Bułhakowa i Hansa Ursa Balthasara".

${ }^{8}$ Por. artykuł odredakcyjny, ,Sodalitium” 50 (1999) 39. 
„Pamiętajmy, ze Ciało mistyczne Chrystusa oczekuje swego zjednoczenia, u końca historii, kiedy wszystkie członki będą zjednoczone w doskonałej szczęśliwości i Bóg będzie cały we wszystkich (następuje odwołanie do Orygenesowej VII homilii do Księgi Kapłańskiej). Rzeczywiście Kościół ma nadzieję zbawienia wiecznego dla wszystkich dzieci i dla wszystkich ludzi"”.

Dokładnie za to Orygenes został potępiony na Soborze Konstantynopolitańskim w 553 r. i trudno przypuścić, by Jan Paweł II o tym nie wiedział.

Stosunkowo często Papież cytuje homilie Orygenesa do Psalmów, te sparafrazowane przez Hieronima, co zwykle podkreśla. Między innymi, gdyż niewątpliwie nie odnotowałem wszystkich przypadków, na audiencjach generalnych w czerwcu 2002 i marcu 2003 r., w których nazywa go ,pisarzem chrześcijańskim" ${ }^{10}$, a także podczas audiencji w Castel Galdolfo w sierpniu 20 VIII 2003 oraz w styczniu 2005 r., kiedy to nazywa go już ,,wielkim pisarzem chrześcijańskim III wieku",11, a także w maju 2003 r., gdzie Orygenes nazwany jest „słynnym pisarzem chrześcijańskim III wieku”"12. Trzeba jednak zauważyć, że sekretarze Jana Pawła II nie popisali się w tych tekstach wielką znajomością metodologii, gdyż wszystkie cytaty z homilii Orygenesa odnoszą do stron w wydaniu włoskim, bez podawania numeru homilii i lokalizacji ich oryginalnego tekstu. Znacznie lepiej wykazali się sekretarze pomagający Papieżowi w przygotowaniu tekstów poważniejszych, jak List Apostolski Dies Domini ${ }^{13}$,

9 Pregendo per i morti la Chiesa contempla prima di tutto il mistero della risurezzione di Cristo (2 VI 1998) 4, Insegnamenti XXI/1, s. 1268.

${ }^{10}$ Por. Salmo 97: il trionfo del Signore alla sua venuta finale (6 XI 2002) 5, Insegnamenti XXV/ 2, s. 673: „In questa prospettiva Origene, scrittore cristiano del terzo secolo, in un testo ripreso poi da san Girolamo, interpreta il «canto nuovo» del Salmo"... przytacza duży cytat (Origene Gerolamo, 74 omelie sul libro dei Salmi, Milano 1993, 309-310); Salmo 89: su di noi sia la bontà del Signore (26 III 2003) 5, Insegnamenti XXVI/1, s. 381: „Così, per lo scrittore cristiano Origene, nel suo Trattato sui Salmi, a noi giunto nella traduzione Latina di San Girolamo" + krótki cytat z Orygenesa (Origene - Gerolamo, 74 omelie sul libro dei Salmi, s. 652)

11 Por. Salmo 147: la Gerusalemme riedificata (20 VIII 2003) 4, Insegnamenti XXVI/2, s. 14: „Anzi, il grande scrittore cristiano del terzo secolo, Origene, ha identificato quel frumento come segno di Cristo stesso, e in particolare, della Sacra Scrittura. Questo è il suo commento" + duży cytat (Origene - Gerolamo, 74 omelie sul libro dei Salmi, s. 543-544); Salmo 114: rendimento di grazie (26 I 2005) 5, Insegnamenti XXVIII/1, s. 107: „Vorremo riprendere in finale i passi piu importanti del Salmo, lasciandoci guidare da un grande scrittore cristiano del III sec., Origene, il cui commento in greco al Salmo 114 ci è giunto nella versione latina di San Girolamo [...] come commenta lo stesso Origene" + duży cytat (Origene - Gerolamo, 74 omelie sul libro dei Salmi, s. 409-412).

12 Por. Salmo 107: lode a Dio e invocazione di aiuto (28 V 2003) 3, Insegnamenti XXVI/1, s. 847: „Commentado questo Salmo, Origene, il celebre scrittore cristiano del terzo secolo, rimanda alla frase di Gesu" + duży cytat (Origene - Gerolamo, 74 omelie sul libro dei Salmi, s. 367).

13 Por. Dies Domini (31 V 1998) 83, w: Listy Apostolskie Ojca Świętego Jana Pawła II, Kraków 2007, 612: „w tym sensie można odczytać słowa Orygenesa, wedle którego doskonały chrześcijanin «zawsze żyje w dniu Pańskim, zawsze świętuje niedzielę» (Contra Celsum VIII 22, SCh 150, 222-224)". 
czy Adhortacja Apostolska Redemptoris custos $^{14}$, gdzie odniesienia są prawidłowe, z podaniem ponadto tomu i stron serii „Sources Chrétiennes”. Podobnie w katechezie o Liturgii Godzin z kwietnia 2001 r. znajdujemy porządne odniesienie do dziełka $O$ modlitwie z podaniem ponadto tomu i kolumny Patrologii Greckiej Migne'a ${ }^{15}$.

$\mathrm{Z}$ wielkim uznaniem wspomina też Orygenesa w Liście Apostolskim Operosam diem - na 1600. rocznicę śmierci Ambrożego; pisze tam o nim jako o najważniejszym z mistrzów Ambrożego ${ }^{16}$.

Z konsekwentnym rozróżnieniem na pisarzy chrześcijańskich i na Ojców Kościoła, z zakwalifikowaniem Orygenesa do pierwszej grupy, spotykamy się natomiast w przemówieniu na lotnisku w Kairze w lutym 2000 roku. Wiemy, że Papież przywiązywał do tej podróży bardzo wielką wagę i między tamtejszymi Koptami stąpał jak na ostrzu brzytwy nie chcąc nikogo urazić. Mówił tam nawiązując do świetnej historii chrześcijańskiego Egiptu:

„W czasach chrześcijańskich, miasto Aleksandria, gdzie Kościół został założony przez Marka Ewangelistę, ucznia Piotra i Pawła, wydało znanych pisarzy chrześcijańskich, jak Klemens i Orygenes, oraz wielkich Ojców Kościoła jak Atanazy i Cyryl. Sława Katarzyny Aleksandryjskiej przetrwała w pobożności chrześcijańskiej i w tytułach wielu kościołów w każdej części świata. Egipt, ze świętym Antonim i świętym Pachomiuszem, był miejscem narodzin monastycyzmu, który odegrał istotną rolę w podtrzymaniu tradycji duchowej i kulturalnej Kościoła"17.

W tak ważnym przemówieniu, w którym trzeba się starać, by niczym nie urazić gospodarzy, a równocześnie nie narazić się „swoim”, precyzacje są potrzebne.

Na koniec ciekawostka, którą podaję tylko w oparciu o wiadomości ustne. Pierwsza pochodzi od o. Bazylego Studera, który podczas któregoś z wykładów na Augustinianum mówił, że zwrócił się do Stolicy Apostolskiej z wnioskiem o rehabilitację Orygenesa. Odpowiedziano mu, jak opowiadał, że nie ma powodu, gdyż nikt nie neguje znaczenia i wielkości Orygenesa, co widać chociażby w licznych cytatach z jego pism w dokumentach Vaticanum II.

14 Por. Redemptoris custos (15 VIII 1989) 9, w: Adhortacje Apostolskie Jana Pawła II, t. 1, s. 503-504: „,Teologiczny sens tego historycznego faktu, bynajmniej nie drugorzędnego, dobrze ujmuje Orygenes" + duży cytat (Homilia XI in Lucam 6, SCh 87, 196n).

${ }^{15}$ Por. La Liturgia delle Ore, preghiera della Chiesa (4 IV 2001) 5, Insegnamenti XXIV/1, s. 659: „Scrive a tal proposito Origene: «Prega senza posa colui che unisce la preghiera alle opera e le opera alla preghiera» (Origenes, De oratione 12, 2, PG 11, 452C)".

${ }^{16}$ Por. Operosam diem (1 XII 1996) 5, w: Listy Apostolskie Ojca Świętego Jana Pawła II, s. 517: „oddał się usilnie studiom biblijnym i teologicznym, badając Pismo Święte i źródła wielkich Ojców o najwyższym autorytecie, a także starożytnych pisarzy kościelnych, zarówno łacińskich jak i greckich, wśród których szczególne miejsce zajmował Orygenes, jego stały mistrz i źródło natchnienia".

17 Por. La pace sia con voi. Questa è la preghiera che elevo per l'Egitto e per il suo popolo (24 II $2000)$ 2, Insegnamenti XXIII/1, s. 249. 
Inną zgoła odpowiedź miał otrzymać śp. o. Henri Crouzel. Otóż opowiadał mi swego czasu, że z okazji okrągłej rocznicy urodzin Orygenesa, przed rokiem 1986, zwrócił się do Stolicy Apostolskiej z prośbą, by Ojciec Święty opublikował jubileuszowy list dla uczczenia Orygenesa. Odpowiedziano mu z którejś Kongregacji watykańskich - nie pamiętam, z której - że jest to niemożliwe, gdyz postawiłoby to w złym świetle nauczanie V Soboru Powszechnego w Konstantynopolu (553) oraz autorytet św. Hieronima. Nie byłoby w tym nic nadzwyczajnego, gdyby nie fakt, iż podobną odpowiedź udzieliło Święte Oficjum już w marcu 1650 r. w sprawie apologii Orygenesa napisanej w Belgii, przez o. Pierre Halloix. Dzieło to nazywało się: Origenes defensus, sive Origenis Adamantii presb[iteris], amatoris Iesu, vita, virtutes, documenta. Item veritatis super eius vita, doctrina, statu, exacta disquisitio. Auctore R.P. Petro Halloix, Leodiensi, Societatis Iesu Theologo, ad Sanctissimum D.N. Papam Innocentium X, Leodii 1648. Ex officina Typographica Henrici et Ioannis Matthiae Hoviorum. Na stronie tytułowej jest ponadto grafika sceny kuszenia w raju.

Prawdziwe apologetyczne zamiary autora wyrażał już podpis pod grafiką na stronie tytułowej: Virtuti comes invidia - cnocie towarzyszy zazdrość. Jezuiccy cenzorzy z Kurii Generalnej w Rzymie pozwolili na wydanie i książka ukazała się. Wtedy jednak, z dwuletnim opóźnieniem, Święte Oficjum kazało wstrzymać sprzedaż książki i wprowadzić konieczne poprawki. Pierwsza dotyczyła usunięcia wszystkiego, co stawia w złym świetle Sobór Konstantynopolitański II, a druga - pisania z większą rewerencją i uszanowaniem o Hieronimie i Epifaniuszu, a także innych, których autorytet autor podważał broniąc Orygenesa, virum dubiae et suspectae fidei ${ }^{18}$. Autor zaproponował poprawki, ale co do Hieronima i Epifaniusza uparł się, że ważniejsza dla niego jest prawda. Nie otrzymał więc żadnej odpowiedzi, książki nie można było wznawiać, a sam tytuł znalazł się na indeksie ksiąg zakazanych z adnotacją: donec corrigatur ${ }^{19}$. Tak więc czasy się zmieniają, a argumentacja Urzędu pozostaje ta sama, mimo tak licznych odniesień do Orygenesa w dokumentach Soboru Watykańskiego II, w Katechizmie Kościoła Katolickiego i w pismach Jana Pawła II.

W indeksach do dzieł Jana Pawła II jest o wiele więcej odniesień do Orygenesa, przytaczanie ich wszystkich wydaje mi się jednak bezcelowe. Chciałem tylko pokazać, że Orygenes przewija się w tych tekstach, że Papież darzył go wielkim uszanowaniem, nazywając „wielkim pisarzem”, a także Ojcem Kościoła wbrew oficjalnym rozróżnieniom na „Ojców” i „Pisarzy”. Uczynił także swoją Orygenesową nadzieję powszechnego zbawienia, narażając się na krytykę współczesnych katarów.

18 Ten dokument i inne w: Claire Falla, L'Apologie d'Origène par Pierre Halloix (1648), Bibliothèque de la Faculté et Lettres de l'Université de Liège 238, Edition „Les Belles Lettres”, Paris 1983, 182-183.

19 Claire Falla, L'Apologie, s. 159. 


\section{ORIGENE NEGLI SCRITTI E DISCORSI DI GIOVANNI PAOLO II}

\section{(Riassunto)}

La communicazione vuol presentare Origene negli scritti e discorsi di Giovanni Paolo II. Soprattutto si fa presente le citazioni dall'Alessandrino nell'enciclica Fides et ratio ed i titoli con i quali il papa lo stava nominando: „scrittore ecclesiastico”, „grande scrittore ecclesiastico”, ma anche „Padre della Chiesa”. Nei testi del papa defunto si vede anche che abbia preso da Origene la speranza della salvezza universale. 